\title{
Communication Design or Graphic Communication Design: Demystifying the Impending Controversy
}

\author{
Dr. Eric Agyarkoh ${ }^{1} \quad$ Helena Alice Mbil $^{2}$ \\ 1. Department of Vocational and Technical Education, Faculty of Science and Technology Education, College of \\ Education Studies, University of Cape Coast, Private Mail Bag, Cape Coast; Ghana \\ 2. University Printing Press, University of Education, Winneba P. O. Box 2, Winneba, Ghana
}

\begin{abstract}
The phrase 'Graphic Design' has been the adopted name for the branch of Visual Art that combines text, illustration and other visual elements to communicate messages. This name has reigned for decades, however, since the emergence of the digital revolution and the information age, different names have been adopted to replace the popular name graphic design. The adaptation of the new names has sparked controversy in the fraternity across the world, and these ideological positions have created confusion among people outside the profession regarding a definite name for the profession. In this paper, the researchers who are part of the fraternity and in academia sought the views and opinions of graphic design tutors in senior high schools in the Cape Coast metropolis in the Central Region of Ghana on the controversy through questionnaire and semistructured interviews, and a total of 10 graphic design tutors were used. The data was analysed and discussed using quasi qualitative-analytical approaches. The findings revealed that, there are diverse entrenched opinions of people in the controversy which does not suggest a possibility of compromise to adopting a definite name soon. To indicate their position in the argument, the researchers employed critical thinking and inductive reasoning to examine the facts that emerged from the views of the tutors discussed, and the findings from the analytical review, and concluded on what they believe should be the appropriate name for the programme.
\end{abstract}

Keywords: Graphic Design, Communication Design, Visual Communication Design and Graphic Communication Design.

DOI: $10.7176 / \mathrm{ADS} / 86-04$

Publication date:October $31^{\text {st }} 2020$

\section{Introduction}

The term "communication" was derived from the Latin word "communis" which means "common". Thus "to communicate" means "to make common, "to make known", "to make public" or "to share" a message (Keyton, 2011). The etymology of the word proves that, the word "communication" is a generic term used to describe the processes of sending information from one source to another. In other words, it is a meaningful exchange of information between two and a group of people. Metts (2004) also believes that, communication should be based on a process in which messages, whether intentional or unintentional, create meaning. This presupposes that unless a common understanding results from exchange of information, there is no communication (Cheney, 2011).

Since human communication occurs between a sender and a receiver, then the art is a social interaction. Study.com (2020) therefore perceives communication as a cyclical process since the message sent must be interpreted by the receiver and give a feedback to the sender. In an attempt to describe the medium through which communication is effected, Lakoff \& Johnson (1999) stated that, humans convey information through a variety of methods: speaking, telephones, email, blogs, TV, art, hand gestures, facial expressions, body language and even social contexts. These means of communication highlighted by Lakoff \& Johnson (1999) were also buttressed by Cheney (2011) and Study.com (2020). Cheney (2011) stated that, in communication, the message is sent through a medium or channel, which is the carrier of the communication. The medium can be a face-toface conversation, telephone call, e-mail, or written report. Study.co. (2020) on the other hand, classified the communication medium into speaking, writing, video transmission, audio transmission, electronic transmission through emails, text messages and faxes and even nonverbal communication, such as body language.

Audio communication transmits messages through air waves and such messages are perceived with the auditory sense. The items used in audio communication are: Radio, Telephone, Tape recorder, CDs, MP3 etc. Visual communication transmits a message through graphic images. In visual communication, the message can be seen as graphic images but cannot be heard. Visual messages are perceived with the visual sense known as the eye. Items use to transmit visual messages are printed, drawn, written and painted works such as books, signboards, signposts, billboards, logos, magazines, photographs, drawings, paintings, diagrams, charts etc. (Simplicable.com, 2020).

Audio-visual communication combines visual and audio media to transmit a message. With audio-visual communication, the message can be seen and at the same time heard. Items used in audio-visual communication are Television, Computers, Mobile phones, Video sets etc. Gestural communication sends messages with signs 
created by body movement. This includes nodding of head, waving or flipping of hands etc. Gestural communication is mostly used to communicate to people who are suffering from hearing impairment. It is popularly known as Sign language (Study Study.com, 2020).

Logically, it is obvious from the above classification of communication mediums that, Graphic design comes under visual communication media. Even though this conclusion is correct, many developmental factors have expanded the scope of graphic design beyond visual communication design. It is these developments that have created the confusion in the fraternity regarding appropriate name that can clearly describe the profession. In this paper, the researchers sought the views and opinions of graphic design tutors in senior high schools in a metropolis in Ghana, used critical thinking and inductive reasoning to analyse the data and discussed the findings in comparison with the adopted names, and finally indicated their position in the controversy. To ground their argument with cogent premises, the researchers developed and reviewed a conceptual framework and did analytical reviews of the adopted names to justify their position in the argument.

\section{Conceptual framework}

To enable the researchers back their opinion with reasonable augments, they opine that, it will be appropriate to relate the review of the various adopted names with a conceptual framework that will explain various factors that they believe must influence an attempt to create a name for an academic programme. Figure 1 is the conceptual framework they developed to explain factors to consider when creating a name for an academic programme.

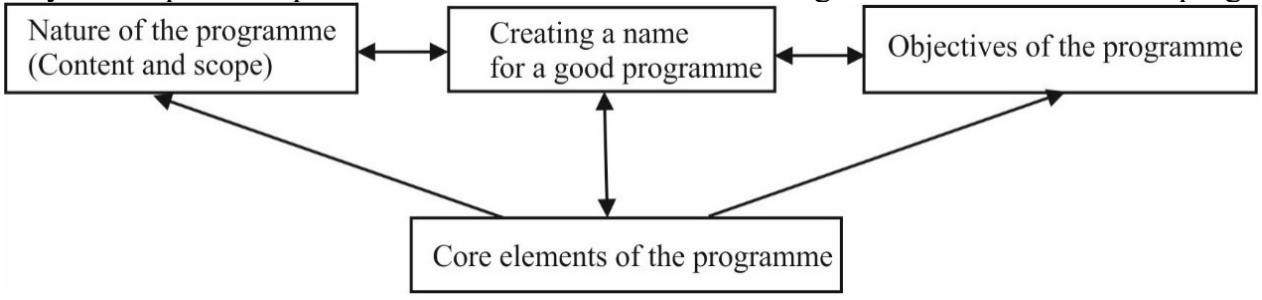

Figure 1: Conceptual framework: Factors to consider when creating a name for a programme (Source: Researchers' Construct, 2020)

The framework actually indicates how variables such as nature, objectives and core elements of a programme influence the name of a programme. Since naming is an element of branding, it is imperative that basic principles of creating brand identity are considered in our quest to proposing a name for the programme. The researchers' association of the name of the programme to brand identity is highlighted by the description of brand given by the American Marketing Association (AMA) cited in Keller (2013) which explained brand as a name, term, sign, symbol, or design, or a combination of them, intended to identify the goods and services of one seller or group of sellers and to differentiate them from those of competition. The concept of brand is also buttressed by Bastos and Levy (2012), who explained it as a product, service, person, company, or a concept which has characteristics like a name, symbol, and many more. Bastos and Levy (2012) further argues that, for a product to be differentiated from others in the market, it must have a face identity such as name.

These explanations of the term brand reveal that the name of the programme should differentiate it from other forms of communication and design professions. It is obvious that this unique identity can only be achieved by the name if the above variables are considered in creating the name. fabrikbrands.com (2020) also opines that, a good brand name must enhance the brand potential, market appeal, visibility and uniqueness of the product. These qualities of a good brand name can be achieved in the naming of the programme if all the variables highlighted in the conceptual framework are considered in adopting a name for the programme. Having justified the importance of the variables highlighted in the conceptual framework in the adaptation of a name for the programme, the researchers will do analytical review of various names that have been crafted for the profession and reveal their inherent characteristics.

\section{Analytical Review of Some Adopted Names \\ 3.1. Graphic Design}

The word 'Graphic' is used to describe any two-dimensional visual image that has meaning or not. Examples of such images include text, pictures, symbols, shapes and other visual elements such as colour, space, texture, lines, dot and others (Merriam-webster.com, 2020). Design in the context of graphic communication means, the process of planning, executing and displaying a graphic communication message to the public. This medium of displaying the graphic message occurs in the production of art forms such as signposts, signboards, billboards, banners, books, brochures, logos, labels, leaflets, posters, wrappers, postage stamps, currencies, invitation cards, and others (Tuckwell, 1992).

Graphic design is also explained as the process of visual communication and problem-solving through the use of typography, photography and illustration. The field is considered a subset of visual communication and communication design, but sometimes the term "graphic design" is used synonymously (Wikipedia.org, 2019). 
Wikipedia.org (2019) again reports that, the phrase 'Graphic design' was coined by William Addison Dwiggins in1922 to describe his process of designing books as combination of typesetting, illustration and design. Prior to the invention of the term 'graphic design,' people who practiced graphic design were described according to the kind of graphic communication work(s) they produced. During the medieval period for instance, master calligraphers who worked in scriptoriums were called scribes, in the renaissance era; inventors of typefaces, reproduction processes were called typographers and printers respectively. Notable among them are William Caxton, Eric Gill, Johann Guttenberg, Albert Durii and others. Also, post renaissance European artists such as Jules Cheret, Henri de Toulouse-Lautrec and Alloys Senefelder who researched and invented modern printing and poster design techniques in the 1800s were called printers and poster artists (Dannis \& Jenkins, 1988). Analysis of the terms 'graphic' and 'graphic design and their historical antecedent reveal that the art is a form of visual communication that has been using text alone or combines text with illustration and other visual elements to plan and communicate a message to the public through art forms. Figures 2, 3 and 4 show examples of the three main classifications of graphic design works:

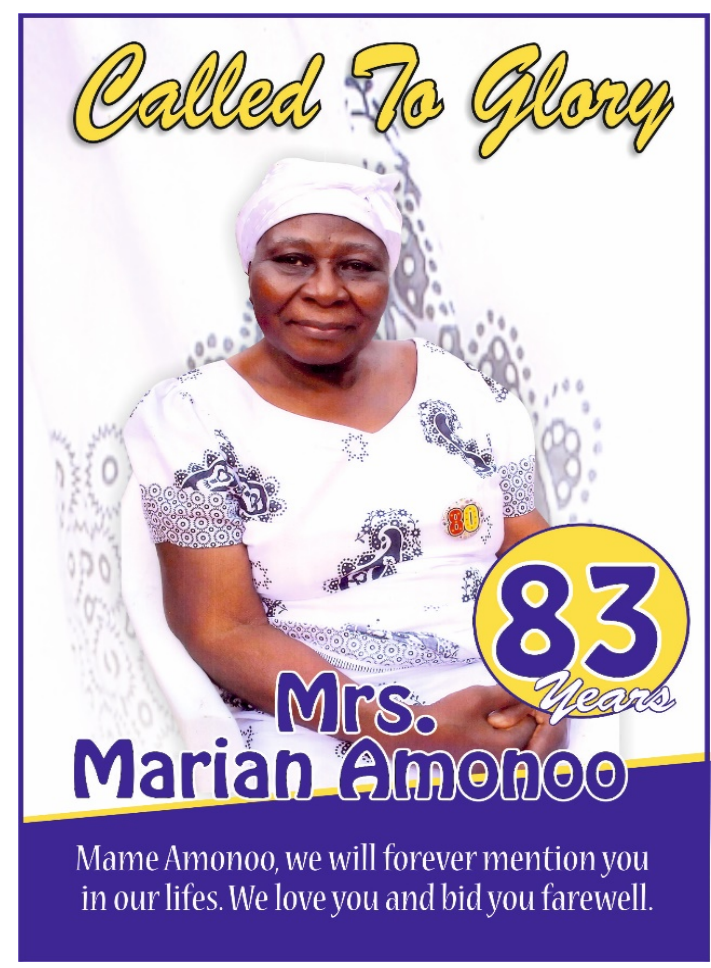

Figure 2: Illustration and text-based graphic Design work.

Researcher's Created Pictorial Poster, (2020)

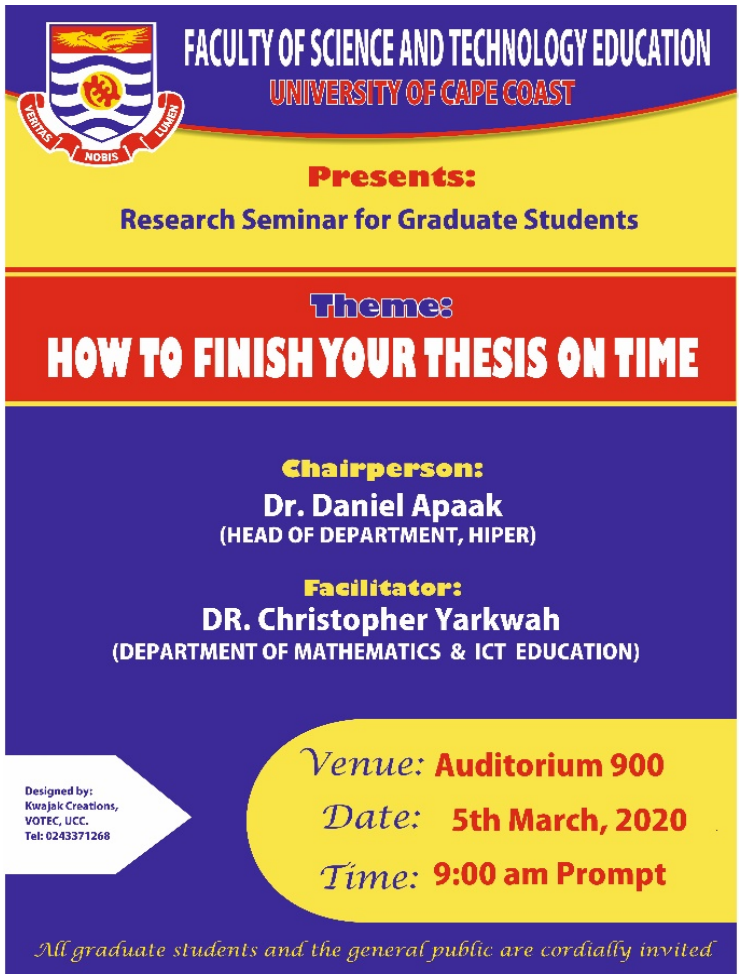

Figure 3: Text-based graphic design work Researcher's Created Poster, (2020)

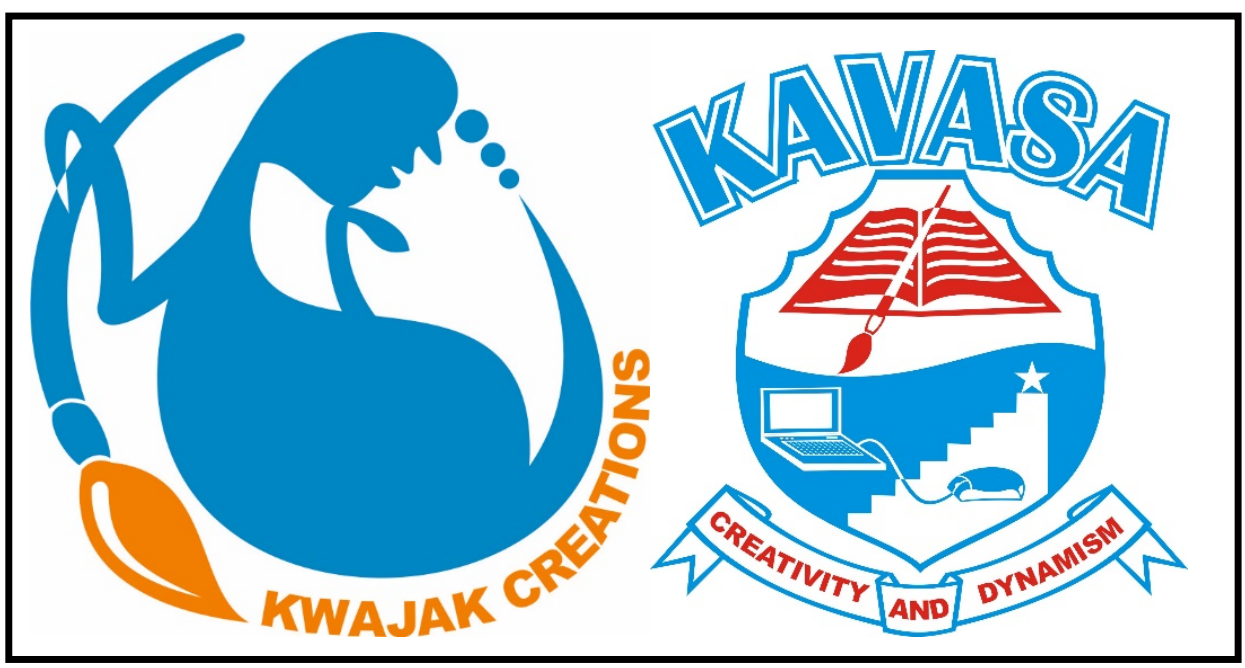

Figure 4: Symbol-based graphic design works Researcher's Created Logos, (2020) 
Even though the name graphic design was coined in the $19^{\text {th }}$ Century, it is the oldest name adopted for the profession by modern graphic designers. The researcher is of the opinion that the invention of the name by William Addison Dwiggins was appropriate because it vividly defined the scope of the profession in that period.

\subsection{Visual Communication Design}

Visual communication is the transmission of information and ideas using symbols and imagery. It is believed to be the type that people rely on most, and it includes pictures, paintings, symbols, graphic designs, films, typography, gestures, and countless other examples (study.com 2019). The website further reports that, evidentially, visual communication is the oldest form of communication since its antecedent can be traced from thousands of years ago, some dating back as far as 40,000 years. Visual communication has evolved from primitive cave paintings called pictographs which were rendered on cave walls and ceilings by the pre-historic men to portray their hunting and spiritual activities. As societies became more advanced, travelling brought people that spoke different languages into contact with each other (Adams 2002).

In order to communicate, people developed ideograms around the 4th millennium BC as a way of social interaction. Ideograms are images that represent physical objects and were used to share ideas or ask questions. Further experiments led to the invention of hieroglyphics in BC 4000 by ancient Egyptians. This was a form of picture writing in which symbols were used to represent sounds so the Egyptians could combine their symbols to write a word. This breakthrough marked the beginning of phonographic communication (Ancient origins.net (2020). The ability to communicate visually opened upon the invention of woodblock printing around the year 600 B. C. The printed word and other symbols allowed for ideas and information to be reproduced, shared, and preserved in a non-verbal way (study.com 2019).

In 1200 B.C., the Phoenicians invented twenty-two-character alphabetic systems consisting of only consonants. It was widely adopted across the world until the Greeks improved upon the characters by converting some to vowels. The Romans also adopted the Greek alphabets and formalised it into 23 characters by A. D. 114 . Importing experience from hieroglyphics writing, different societies experimented and eventually developed a system of handwriting called calligraphy which became a brush hand across the world until the invention of moveable type by Johannes Gutenberg in A.D. 1440 and different styles of typefaces in the renaissance period in Europe (Dannis \& Jenkins, 1988).

The art of visual communication design was elevated in the renaissance period when paintings and illustrations became the dominant form of visual communication in Europe (Getlein, 2002). In the $15^{\text {th }}$ Century, the renaissance painters used painting, letterpress and intaglio printing processes to produce paper posters (Broadsides). These posters were mostly text-based with few hand-drawn or painted illustrations (Art Source International Inc. 2016).

The inventions of still-picture photography by Joseph Nicephore Niepce in 1826, half-tone photography by Stephen H. Horgan in 1875 and lithographic printing by Alois Senefelder in 1789 in Europe also contributed immensely to the development of Visual Communication design across the world (Adams, Faux and Rieber,1988) and (Getlein, 2002).

Taking inspiration from the $15^{\text {th }}$ Century broadside posters, a post-renaissance painter called Jules Cheret combined his skills in drawing and painting with typography, photography and lithography to produce captivating pictorial commercial posters in 1858 in France. His move attracted other European painters of the period such as Henri de Toulouse-Lautrec, Alphonse Mucha and others to join the craft (Dannis \& Jenkins, 1988) and (Art Source International Inc. 2016).

As technology continued to improve after World War II, inventions in Internet technology, digital photography and printing technology ushered in the digital revolution and the information age in Europe and America which has gradually spread across all continents through globalisation. These technologies have widened the scope of visual communication design and improved it quality. For instance, sophisticated cameras are available to record videos and edit them to produce films. Quality still-pictures can also be recorded from the environment and manipulated in so many ways. Text, illustrations, videos and animations are also synchronised to produce integrated interactive visual communication design products. Figures 5, 6, 7, 8 and 9 indicate some forms of visual communication works. 


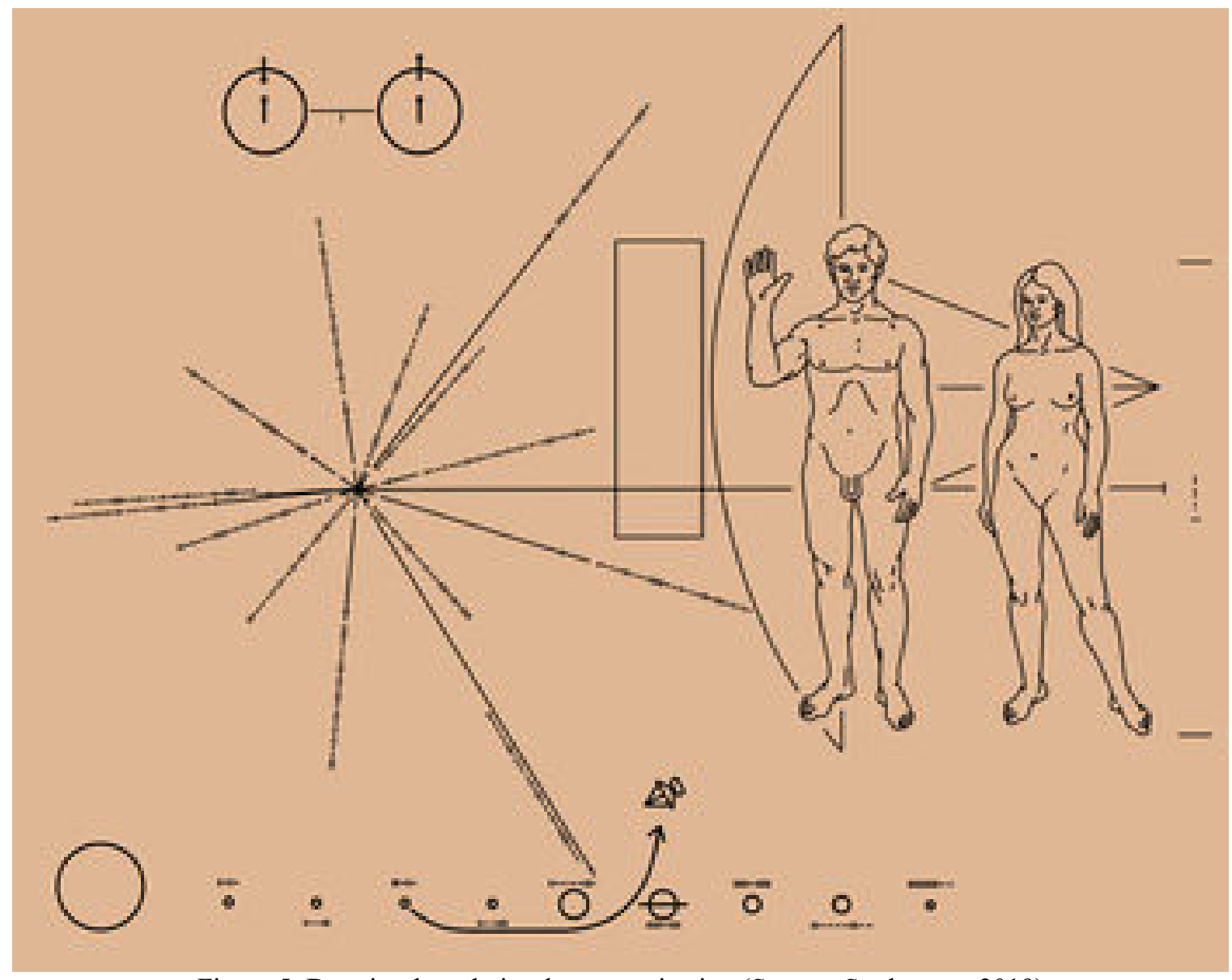

Figure 5: Drawing-based visual communication (Source: Study.com, 2019)

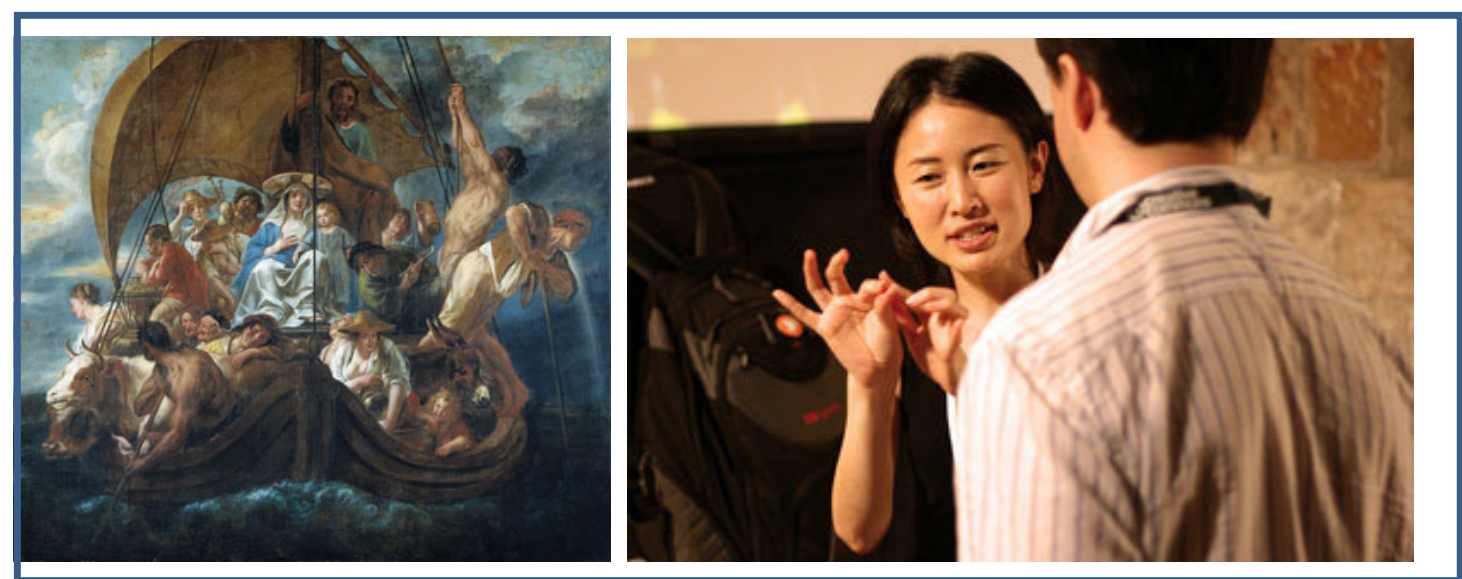

Figure 6: Picture-based visual communication (Source: Study.com, 2019) 


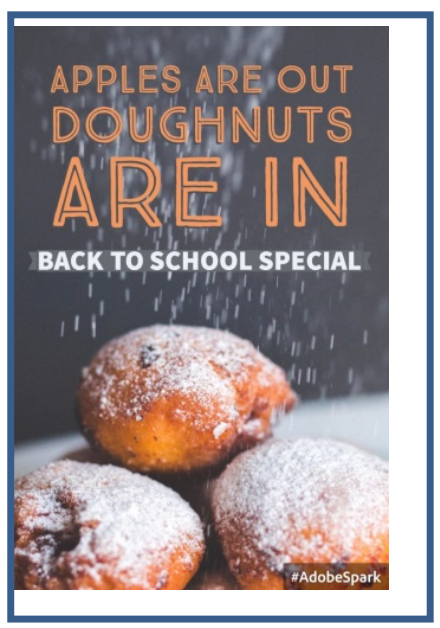

Figure 7: Picture and Text-based Visual communication (Source: Study.com, 2019)

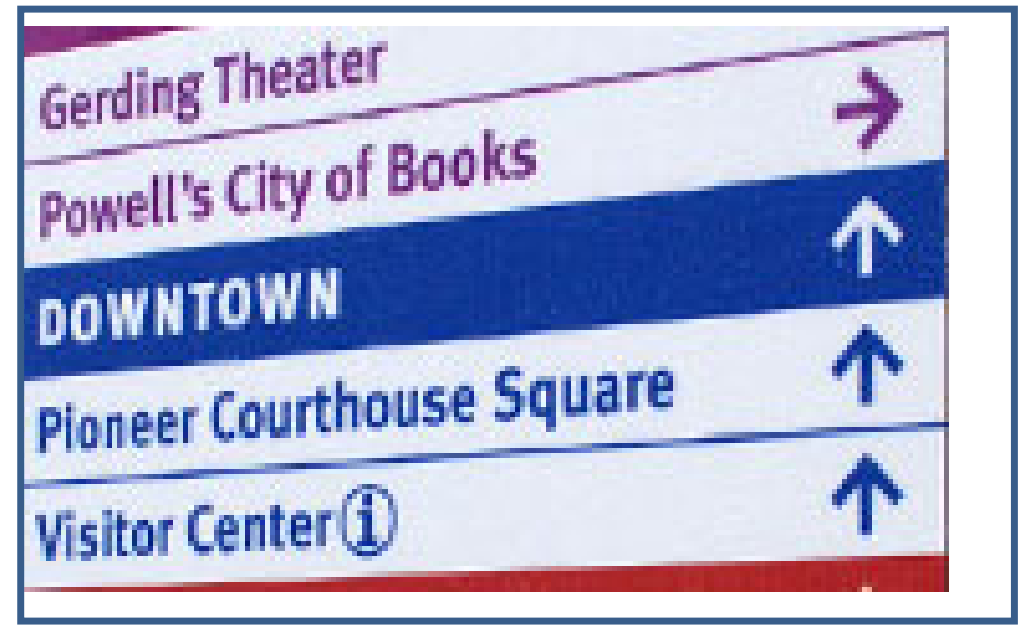

Figure 8: Text-based visual communication (Source: Study.com, 2019)

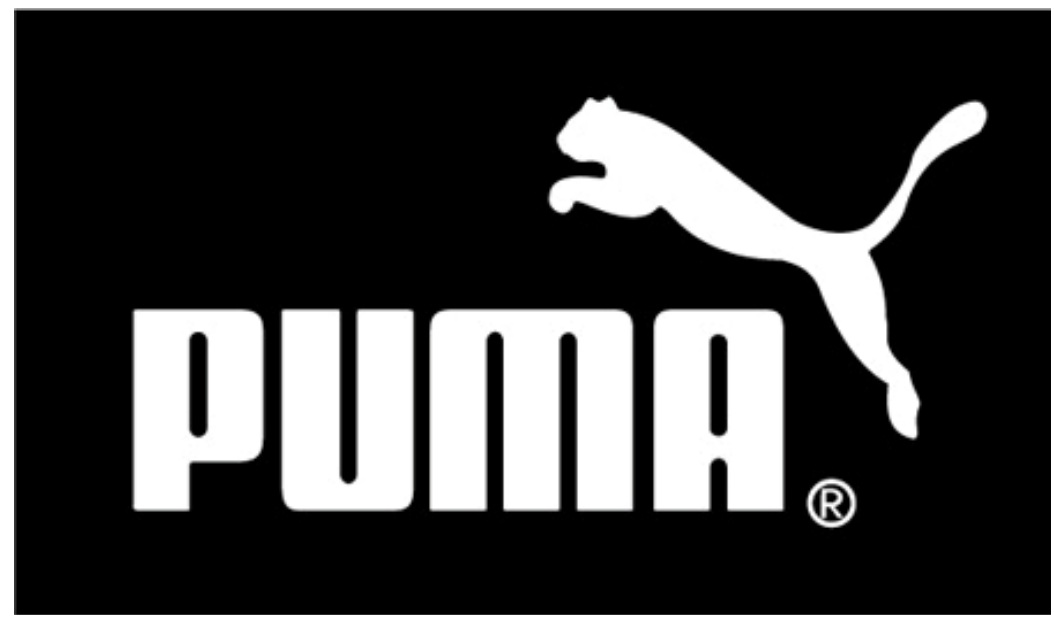

Figure 9: Symbol/sign-based visual communication (Source: Study.com, 2019)

A study of the scope, characteristics and historicity of visual communication design from its crude beginnings to its current digital status, indicate that, it has always been characterised by the use of visual imagery such as text, photographs, pictures, drawings, paintings, graphic design works, videos, animations, webpages, and others. It is therefore obvious that visual communication uses only one or combines two or more of the communication elements to generate message to communicate.

\subsection{Communication Design}

The phrase 'Communication design' is a modern term that has been coined to describe the scope of contemporary planned communication which transcends beyond the use of visual communication elements to embrace sound. Luminant design LLC (2014) for instance, describes communication design as the practice of planning and shaping a message in content, form and delivery. The organisation further highlighted that, the medium employs effective and expressive ways of sharing ideas with others, using an approach that focus on both problem-solving and persuasion. In other words, communication design is about message and effect. It focuses on touching people through transmission of ideas. Therefore, communication design comes with a responsibility to compassionately understand the recipient's existing perceptions and systems of beliefs, while designing solutions that fulfil the sender's goals in sharing his/her ideas. Luminant design LLC (2014) also opines that, the name communication design extends beyond visual communication to embrace other forms of planned communication and stated information design, information architecture, Interaction Design, User Interface Design, Information Ecology Way-finding Design, advertising and marketing as the scope.

The Society of Graphic Designers of Canada (2019) also explains communication design as involving effective visualisation of communication concepts, primarily in print and electronic media (including interface design). The society further acknowledges that, from 1960s to date, communication design has emerged as a complex service-profession. While pioneering designers honed their craft on paper by hand, today's designers are 
at the forefront of technology, using complex computer software and the latest printing techniques to communicate ideas (Society of Graphic Designers of Canada, 2019). In other words, communication design is a modern communication medium that combines art, psychology and technology to generate and communicate ideas.

Communication design is a mixed discipline between design and information-development which is concerned with how media intervention such as printed, crafted, electronic media or presentations communicate with people. A communication design approach is not only concerned with developing the message aside from the aesthetics in media, but also with creating new media channels to ensure the message reaches the target audience (Wikipedia.org, 2019).

Sharing his opinion on the scope of communication design, Leon Alvarado, a renowned designer stated on Quora.com (2018) on Jan 14, 2018 that, Communication design encompasses a wide variety of areas but the best of it is to communicate a particular idea by using a problem-solving approach and a bit of psychological persuasion. He suggested the scope of communication design to include packaging, billboard, print ads, radio and television, social media, and others. He however emphasised that, even though radio advertisements do not involve visual design per se but the verbiage must have some elements that tie it with the visual look of the brand and the rest of the advertising efforts.

\section{Methodology}

The researchers adopted quasi qualitative-analytical approach for the study. A total of 9 graphic design tutors were used as participants and they were purposively selected from all the 9 public senior high schools in the Cape Coast metropolis in the central region of Ghana that offer Visual Arts as a programme. Two different criteria were used to select them according to the type of instruments they answered: All of them responded to the questionnaire but only 4 of them were interviewed. These categories were interviewed because they have taught graphic design for 15 years and above which presupposes that they are more experienced in graphic design education than the others. Table 1 is the sample distribution of the study:

Table 1: Sample Distribution Table (Source: Fieldwork, 2020)

\begin{tabular}{|l|l|c|c|c|}
\hline No. & Name of School & $\begin{array}{l}\text { Graphic Design } \\
\text { Tutors< 15Yrs. }\end{array}$ & $\begin{array}{l}\text { Graphic Design } \\
\text { Tutors >15 Yrs. }\end{array}$ & No of participants selected \\
\hline 1 & Holy child SHS & $\checkmark$ & & 1 \\
\hline 2 & Mfantsepim SHS & & $\checkmark$ & 1 \\
\hline 3 & Adisadel College & $\checkmark$ & $\checkmark$ & 1 \\
\hline 4 & Aggrey Memorial SHS & & & 1 \\
\hline 5 & Ghana national SHS & $\checkmark$ & & 1 \\
\hline 6 & University practice SHS & & $\checkmark$ & 1 \\
\hline 7 & Ogua Senior high Tech & $\checkmark$ & & 1 \\
\hline 8 & $\begin{array}{l}\text { Academy Christ the King } \\
\text { SHS }\end{array}$ & & $\checkmark$ & 9 \\
\hline 9 & Efutu Senior High Tech. & & 5 & 1 \\
\hline
\end{tabular}

Total Number of Participants $=9$

The researchers used questionnaire and semi-structure interview guide to collect data. Both instruments were administered by the researchers in the schools. Samples of the instruments have been placed in appendices $\mathrm{A}$ and $\mathrm{B}$ respectively. To observe ethical standards in the study, the researchers introduced themselves to the headteachers of the schools' verbally and proved their authenticity with their institutional ID cards and briefed them about the study. They were subsequently permitted to contact the tutors in the Visual Arts departments. Upon identifying the relevant tutors for the study, the researchers briefed them about the study and sought their consent verbally. The researchers assured all the tutors of ensuring their privacy, anonymity and confidentiality in the study. The use of ethical considerations and trustworthiness in qualitative research is emphasised by Guba, E. G. (1981).

\section{Method of Data Analysis and Presentation of Findings}

The questionnaire retrieved from the respondents were analysed and presented in simple frequency tables. The responses obtained from the semi-structured interview guides were also organised and tabulated under the various questions posed. Tables 2, 3, 4. 5, 6 and 7 are the analysis of the questionnaire and interview guide respectively: 


\subsection{Analysis of Questionnaire}

Table 2: Biographic Data: Highest Academic Qualification (Graphic Design) (Source: Fieldwork, 2020)

\begin{tabular}{|c|c|c|}
\hline Variables & Frequencies & percentage \\
\hline $\mathrm{PhD}$ & 0 & \\
\hline Masters & 2 & \\
\hline Bachelor & 7 & \\
\hline HND/Diploma & 0 & \\
\hline Certificate & 0 & \\
\hline Total & 9 & 100 \\
\hline \multicolumn{3}{|c|}{ Biographic Data: Highest professional Qualification (Education) } \\
\hline $\mathrm{PhD}$ & 0 & \\
\hline Masters & 1 & \\
\hline Bachelor & 5 & \\
\hline HND/Diploma & 2 & \\
\hline Certificate & 1 & \\
\hline Total & 9 & 100 \\
\hline
\end{tabular}

Table 3: Biographic Data: Years of Teaching Graphic Design (Source: Fieldwork, 2020)

\begin{tabular}{|c|c|c|}
\hline Variables & Frequencies & percentage \\
\hline $1-5$ Years & 3 & \\
\hline 6-10 Years & 1 & \\
\hline $11-15$ Years & 1 & \\
\hline 16-20 Years & 2 & \\
\hline More than 20 Years & 2 & \\
\hline Total & 9 & 100 \\
\hline
\end{tabular}

Table 4: Characteristics of Graphic Design (Source: Fieldwork, 2020)

\begin{tabular}{|c|c|c|c|c|c|c|c|}
\hline \multirow[t]{2}{*}{ Variables } & \multicolumn{7}{|c|}{ Frequencies } \\
\hline & $\begin{array}{l}\text { Strongly } \\
\text { agree }\end{array}$ & Agree & Disagree & $\begin{array}{l}\text { Strongly } \\
\text { Disagree }\end{array}$ & $\begin{array}{l}\text { Not } \\
\text { Certain }\end{array}$ & Total & Percentage \\
\hline $\begin{array}{l}\text { Graphic design can } \\
\text { combine text, illustration } \\
\text { and colour to communicate } \\
\text { information }\end{array}$ & $7(77.7 \%)$ & $2(22.2 \%)$ & $0(0 \%)$ & $0(0 \%)$ & $0(0 \%)$ & 9 & 100 \\
\hline $\begin{array}{l}\text { Graphic design can } \\
\text { combine only text and } \\
\text { illustration to communicate } \\
\text { information }\end{array}$ & $4(44.4 \%)$ & $2(22.2 \%)$ & $0(0 \%)$ & $3(33.3 \%)$ & $0(0 \%)$ & 9 & 100 \\
\hline $\begin{array}{l}\text { Graphic design can use } \\
\text { only text and colour to } \\
\text { communicate information }\end{array}$ & $5(55.5 \%)$ & $2(22.2 \%)$ & $2(22.2 \%)$ & $0(0 \%)$ & $0(0 \%)$ & 9 & 100 \\
\hline $\begin{array}{l}\text { Graphic design can use } \\
\text { only illustration and colour } \\
\text { to } \\
\text { information }\end{array}$ & $5(55.5 \%)$ & $2(22.2 \%)$ & $2(22.2 \%)$ & $0(0 \%)$ & $0(0 \%)$ & 9 & 100 \\
\hline $\begin{array}{l}\text { Graphic design can } \\
\text { combine text, illustration, } \\
\text { colour and other visual } \\
\text { elements to communicate } \\
\text { information }\end{array}$ & $9(100 \%)$ & $0(0 \%)$ & $0(0 \%)$ & $0(0 \%)$ & $0(0 \%)$ & 9 & 100 \\
\hline
\end{tabular}


Table 5: Characteristics of Graphic Communication Design (Source: Fieldwork, 2020)

\begin{tabular}{|c|c|c|c|c|c|c|c|}
\hline \multirow[t]{2}{*}{ Variables } & \multicolumn{7}{|c|}{ Frequencies } \\
\hline & $\begin{array}{l}\text { Strongly } \\
\text { agree }\end{array}$ & Agree & Disagree & $\begin{array}{l}\text { Strongly } \\
\text { Disagree }\end{array}$ & $\begin{array}{l}\text { Not } \\
\text { Certain }\end{array}$ & Total & Percentage \\
\hline $\begin{array}{l}\text { Graphic communication } \\
\text { design can use the same } \\
\text { visual elements as Graphic } \\
\text { design to communicate } \\
\text { information }\end{array}$ & $4(44.4 \%)$ & $3(33.3 \%)$ & $2(22.2 \%)$ & $0(0 \%)$ & $0(0 \%)$ & 9 & 100 \\
\hline $\begin{array}{l}\text { Graphic communication } \\
\text { design cannot use the same } \\
\text { visual elements as Graphic } \\
\text { design to communicate } \\
\text { information }\end{array}$ & $0(0 \%)$ & $0(0 \%)$ & $2(22.2 \%)$ & $4(44.4 \%)$ & $3(33.3 \%)$ & 9 & 100 \\
\hline
\end{tabular}

Table 6: Characteristics of Communication Design (Source: Fieldwork, 2020)

\begin{tabular}{|c|c|c|c|c|c|c|c|}
\hline \multirow[t]{2}{*}{ Variables } & \multicolumn{7}{|c|}{ Frequencies } \\
\hline & $\begin{array}{l}\text { Strongly } \\
\text { agree }\end{array}$ & Agree & Disagree & $\begin{array}{l}\text { Strongly } \\
\text { Disagree }\end{array}$ & $\begin{array}{l}\text { Not } \\
\text { Certain }\end{array}$ & Total & Percentage \\
\hline $\begin{array}{l}\text { Communication design } \\
\text { can use only one or } \\
\text { combines more than one } \\
\text { visual element used by } \\
\text { Graphic design to } \\
\text { communicate information }\end{array}$ & $5(55.5 \%)$ & $0(0 \%)$ & $2(22.2 \%)$ & $0(0 \%)$ & $2(22.2 \%)$ & 9 & \\
\hline $\begin{array}{l}\text { Communication design } \\
\text { can combine audio, } \\
\text { video, animation, } \\
\text { illustrations and text to } \\
\text { communicate information }\end{array}$ & $7(77.7 \%)$ & $2(22.2 \%)$ & $0(0 \%)$ & $0(0 \%)$ & $(0 \%)$ & 9 & 100 \\
\hline $\begin{array}{l}\text { Communication design } \\
\text { can use only audio to } \\
\text { communicate information }\end{array}$ & $0(0 \%)$ & $0(0 \%)$ & $6(66.6 \%)$ & $0(0 \%)$ & $3(33.3 \%)$ & 9 & 100 \\
\hline $\begin{array}{l}\text { Communication design } \\
\text { can use only video to } \\
\text { communicate information }\end{array}$ & $0(0 \%)$ & $0(0 \%)$ & $4(44.4 \%)$ & $3(33.3 \%)$ & $2(22.2 \%)$ & 9 & 100 \\
\hline $\begin{array}{l}\text { Communication design } \\
\text { can use only animation to } \\
\text { communicate information }\end{array}$ & $0(0 \%)$ & $0(0 \%)$ & $6(66.6 \%)$ & $2(22.2 \%)$ & $1(11.1 \%)$ & 9 & 100 \\
\hline $\begin{array}{l}\text { Communication design } \\
\text { can use only still-images } \\
\text { to communicate } \\
\text { information }\end{array}$ & $0(0 \%)$ & $0(0 \%)$ & $2(22.2 \%)$ & $5(55.50 \%)$ & $2(22.20 \%)$ & 9 & 100 \\
\hline
\end{tabular}




\subsection{Analysis of Semi-Structured Interview Guide}

Table 7: Analysis of Semi-structured Interview Guide (Source: Fieldwork, 2020)

\begin{tabular}{|c|c|}
\hline Variables & Participants and Responses \\
\hline $\begin{array}{l}\text { Should the name Graphic } \\
\text { design be changed? }\end{array}$ & $\begin{array}{l}\text { Participant A: Yes, if the name has become ambiguous } \\
\text { Participant B: No, because it is the effectiveness of the communication that } \\
\text { matters not the name. } \\
\text { Participant C: No, because this have been used since time memorial. } \\
\text { Participant D: If the change can still reflect the purpose and originality of } \\
\text { designing, Why not. }\end{array}$ \\
\hline $\begin{array}{l}\text { Can the change of name } \\
\text { from graphic design affect } \\
\text { the brand and recognition } \\
\text { of the programme? }\end{array}$ & $\begin{array}{l}\text { Participant A: No, the public classify anything done with the computer as } \\
\text { graphic design } \\
\text { Participant B: No, changing the name will not change anything, but stakeholders } \\
\text { must be educated about the programme } \\
\text { Participant C: Yes, the public will face difficulty in recognising the programme. } \\
\text { However, it will not affect the brand because the courses in the programme are } \\
\text { maintained and even broadened. } \\
\text { Participant D: It might take some time before it will settle in the minds of } \\
\text { people. }\end{array}$ \\
\hline $\begin{array}{l}\text { Should a new name be } \\
\text { adopted to reflect the } \\
\text { current scope of the } \\
\text { profession? }\end{array}$ & $\begin{array}{l}\text { Participant A: It will be good for practitioners and also help in job specification } \\
\text { Participant B: No, I don't think it is necessary to adopt new name } \\
\text { Participant C: The old name does not cover everything in the programme } \\
\text { Participant D: Definitely Yes }\end{array}$ \\
\hline $\begin{array}{l}\text { Should the name graphic } \\
\text { design be maintained to } \\
\text { preserve the brand } \\
\text { identity of } r \\
\text { programme? }\end{array}$ & $\begin{array}{l}\text { Participant A: Yes, if changing it will create infusion in the minds of the public. } \\
\text { Participant B: Yes, people are familiar with the name and are comfortable with } \\
\text { it. } \\
\text { Participant C: Yes, because that is what is popularly known } \\
\text { Participant D: I believe the brand has registered already in the profession so } \\
\text { name change will not have effect. }\end{array}$ \\
\hline $\begin{array}{l}\text { Should we combine } \\
\text { elements from different } \\
\text { names to create an } \\
\text { appropriate name for the } \\
\text { programme? }\end{array}$ & $\begin{array}{l}\text { Participant A: Yes, to help in job specification." } \\
\text { Participant B: No, change of name does not matter because the name graphic } \\
\text { design is already known. The change will confuse the public. } \\
\text { Participant C: No, it is not necessary because the programme is already broad } \\
\text { Participant D: Possibly yes, to capture the new wave of design in } \\
\text { communication }\end{array}$ \\
\hline $\begin{array}{l}\text { Which of the adopted } \\
\text { names is appropriate for } \\
\text { the programme and why? }\end{array}$ & $\begin{array}{l}\text { Participant A: Graphic Communication design. It entails all the areas the } \\
\text { programme covers. } \\
\text { Participant B: The name graphic design should be maintained as far as it serves } \\
\text { its purpose } \\
\text { Participant C: graphic communication design, because the programme uses } \\
\text { graphic content to communicate through design. } \\
\text { Participant D: Communication design, I belief this captures all areas employed } \\
\text { in communication to the public }\end{array}$ \\
\hline $\begin{array}{l}\text { Can you suggest a } \\
\text { different name for the } \\
\text { programme and give your } \\
\text { reasons? }\end{array}$ & $\begin{array}{l}\text { Participant A: Visual and digital communication design. This refers to all the } \\
\text { visual and digital design as well as communication design } \\
\text { Participant B: Graphic Design, because it is already popular with the public and } \\
\text { it serves its purpose. } \\
\text { Participant C: Graphic communication design, because it explains and gives } \\
\text { you the idea what the programme entails } \\
\text { Participant D: The scope of different elements entering the domain of the } \\
\text { programme has made it possible for name change in the field. }\end{array}$ \\
\hline
\end{tabular}

\section{Discussions of Findings}

The researchers adopted augmentative approaches such as critical thinking and inductive analysis to discuss the findings that emerged from the field data and the analytical review, and based on sound premixes and emerging facts from the analysis to draw logical conclusions that vehemently support their position in the controversy. The discussion was done in the following order:

\subsection{Discussion of Findings from Field Data}

It is clear from the biographical data of the respondents that majority of the tutors hold bachelor's degree in 
graphic design and education and have taught graphic design at the senior high school level for less than 6 years. However, only few of them have post-graduate degrees and also have taught the programme for more than 15 years. This is indicative that some of the tutors lack high analytical and in-depth knowledge in graphic design and scope and developmental trends in the programme.

In respect of the characteristics of the various names that have been adopted for the programme, majority of the respondents agree that graphic design combines text, illustration and other visual elements such as colour, lines, etc to generate message for communication. It can also combine only illustration and text, and colour and text to communicate. Ironically, majority also think that graphic design can use only illustration and colour to communicate. Even though most of the findings reflect the through characteristics of graphic design as explained by Merriam-webster.com (2020) and Wikipedia.org (2019), their view that graphic design can use only illustration and colour to communicate does not vividly define the characteristic of graphic design.

Also, the findings in which majority of the respondents opine that communication design combines all the elements of graphic design and other non-still images of communication such as animation, video and audio suggest that, the teachers have fair understanding of the scope of communication design because all these characteristics have also been stated by The Society of Graphic Designers of Canada (2019).

Again, majority of the respondents agree that graphic communication design uses the same elements as graphic design to communicate. However, few of them are not certain. This finding means that graphic communication is synonymous to graphic design.

In respect of the views of the controversy about the adaptation of different names for the profession, 2 of the participants did not agree that the name graphic design should be changed because, it is popular among the public and also, the name change do not matter. It is the effectiveness of the communication that matters. The few that said the name graphic design should be changed, stated that it should be done if only the name has become ambiguous and if the change can help achieve the purpose of the programme. Whiles some believe that the change of name will affect the recognition of the programme among the general public, others think the programme has gained its popularity already so merely changing the name will not affect its brand identity.

It was also found out from the analysis that, there are opposing views among the tutors whether elements of different adopted names must be combined to develop an acceptable name for the programme. Whiles some believe that will help in job specification and also indicate current trend of the programme, others think the expansion that has taken place in the programme is already known by the public, so combining elements from different adopted names to create a new name to reflect the scope of the programme is not necessary.

Sharing their views on which of the adopted names is appropriate, majority of the tutors think that the name graphic communication design is the most appropriate because, it entails all the areas the programme covers. Those who think otherwise believe that the name graphic design should not be changed to maintain brand identity of the programme and also the name communication design must be adopted because it captures all areas employed in communication to the public.

The analysis also revealed that three different names were suggested by the participants. Participant ' $A$ ' suggested Visual and Digital Communication Design, and argued that, it captures all the visual and digital design as well as communication design. Participant 'B' suggested Graphic Design because he thinks it is already popular among the public and participant ' $\mathrm{C}$ ' suggested Graphic Communication Design because it gives an idea of what the programme entails. However, participant ' $\mathrm{D}$ ' could not suggest a name but thinks there is the need to adopt a new name.

\subsection{Discussion of Emerging Facts from Analytical Review}

An examination of the facts emerging from the analytical literature reviews revealed to the researchers that, until 1922, the profession did not have a definite name. This could be attributed to the fact that visual communication has a wider scope consisting of different trades which were regarded distinct from each other. For example, painting, illustration, letterpress, engraving, lithography, typography, calligraphy and photography were regarded as specialist vocations in visual communication. The researchers can logically conclude that it was based on deeper understanding and experience in the profession that enabled William Addison Dwiggins to create the name 'Graphic design' to define the profession at that time (Wikipedia.org, 2019).

It also emerged from the reviews that, the name graphic design was maintained until 1960s when the digital revolution and information age emerged in the advanced countries. The dynamism of the internet and the digital technologies broadened the scope of communication mediums. Also, advancement in global communication and marketing moved pragmatic individuals in the internet and digital fraternity to explore various means of creating interactive communication by integrating and synchronising different communication media such as graphics, video, animation and sound. This led to the development of electronic marketing applications called 'new media' which integrated all forms of communication elements to generate and present messages. Apparently, it was the infusion of the new media in communication that made organisations and individuals in the communication and media industry to propose new names for the graphic design profession which will clearly define it current scope. 
Hence the names visual communications design, communication design, graphic communication design and others.

\subsection{Researchers' Justification for their Position in the Controversy}

It is obvious from the facts that emerged from all the reviews, analysis and discussion of findings that, all the authorities and the graphic design tutors agree that, though different names have been adopted for the profession over time, all the new names contain the word 'design' and 'communication' which clearly proves that there is unanimity in the fraternity that, the profession is a form of creative art and a medium of communication. However, the challenge that is creating the confusion in adopting a universal name for the profession is the apparent expansion of the scope of the profession as a result of the advent of the new media technologies.

To justify the superiority of the name the researchers' will propose in this paper, the researchers will base on sound premixes articulated by some of the participants and their own opinion to highlight the reasons why all other names will not be appropriate to define the current scope of the profession except their proposed name.

Firstly, being a form of communication, currently the profession uses visual elements such as Still-Graphics and Motion-graphics to generate messages and sometimes complimented with sound (voice). Also, to achieve legibility, clarity and attraction in and for the message, different psychology and aesthetic theories and principles are applied in the design and production processes. It is clear from this analysis that, the dominant elements used to generate messages in the profession are visual which always include text. Again, even though digital revolution has expanded the scope of graphic communication to include voice, it is obvious that voice constitutes a minor element in contemporary graphic communication. Another factor worth considering is the fact that the name 'graphic design' has ingrained in the minds of the public due to its longevity in the system therefore creating a permanent brand for the profession. This analysis is in consonance with a report from the Information Management and Business Review (2012) as cited in (Singh 2012) which indicated that, the concept of brand has become an integral part of our daily life. The bond between consumer and a strong brand mostly depends on high level of brand awareness and its positive unique association with consumer's memory. This premix is also vehemently emphasised by some of the graphic design tutors in the analysis. This finding further justifies the researchers' position that, the name 'graphic design' has gained unique association with the public's memory. The researchers opine that, an attempt to eliminate the name 'graphic design' completely from the name of the profession will create an impression of a different profession to the public.

\section{Conclusion}

Based on the above justifications, the researchers would suggest that the name 'Graphic Communication Design' be adopted for the profession for the following reasons; the word 'graphic' used in the proposed name will help the public to associate the profession with the established name: 'graphic design'. It will also indicate that, majority of the elements used to generate and present information in the profession are two-dimensional visual images and symbols. This induction is in concurrence with the variable 'nature of the programme' in the conceptual framework which points out the unique characteristics of graphic design. Based on these characteristics, the visual elements should have supremacy over any other non-visual complimenting element(s). The inclusion of the word 'Communication' in the proposed name also emphasis the point that the profession is a specialised area in communication studies and finally, the use of the word 'design' in the proposed name highlights the fact that the profession is a form of creative art.

The researchers still believe that, proposal of the name 'Graphic Communication Design' will spark another controversy among readers of this article because, some people will still think that the inclusion of the word 'graphic' in the prosed name still limits the name to only visual communication and exclude the non-visual elements in the medium. Taking these legitimate concerns and valid arguments into consideration, one can also suggest that the word Graphic be removed completely from the name because of its perceived limitation and adopt a generic name that will embrace all the communication media but still be silent on them. For example, 'Communication Design'.

Even though the researchers can agree on adaptation of a generic name, they still insist on the importance of maintaining over ninety years brand association built with the name Graphic Design across the world, because effective branding of a profession also raise public confidence in the profession and increase patronage.

\section{References}

Adams, Faux and Rieber (1988), "Printing Technology": $3^{\text {rd }}$ Ed. New York, Delmar publishers Inc. pp:169 and 310

Adams, S. L. (2002). “Art Across Times “(2 ${ }^{\text {nd }}$, Edition, Vol. 1). New York: McGraw-Hill Companies Inc.

Ancient Origins.net (2020). "Egyptian Hieroglyphs: The Language of the Gods". Retrieved, 18th ${ }^{\text {th }}$ May, 2020.From: https://www.ancient-origins.net/artifacts-ancient-writings/egyptian-hieroglyphs-language-gods002990. 
Art Source International Inc. (2016). 'History of the Poster.' Retrieved October 5, 2012. Website: http://www.rare-maps.com/poster_history.cfm.

Bastos, W., \& Levy, S. J. (2012). 'A History of the Concept of Branding: Practice and Theory'. Journal of Historical Research in Marketing, 4(3), 347-368.

Cheney, G. (2011). 'Organizational Communication in an Age of Globalisation: Issues, Reflections, Practices'. Long Grove, IL: Waveland Press.

Dannis A. E. \&Jenkins D. J. (1988). “Comprehensive Graphic Arts” (3 ${ }^{\text {rd }}$ ed.). New York: Glencoe McGrawHill Company.

fabrikbrands.com (2020). 'Product naming Ideas: Why are They So Important?', Retrieved, $15^{\text {th }}$ January, 2020 at 1:16an. Website: https://fabrikbrands.com/how-to-name-a-product/

Getlein, M. (2002). ' 'Gilbert's Living with Art'’ (6 ${ }^{\text {th }}$ ed.). New York: McGraw-Hill Companies Inc.

Guba, E. G. (1981). "Criteria for Assessing the Trustworthiness of Naturalistic Inquiries"'. Educational Communication and Technology Journal 29 (1981), 75-91.

Keller, K. L. (2013). 'Strategic Brand Management: Building, Measuring, and Managing Brand Equity'. (Global Edition). England: Pearson Education Limited.

Keyton, J. (2011). 'Communication and Organizational Culture: A Key to Understanding Work Experience'. Thousand Oaks, CA: Sage.

Lakoff, G. and Johnson, M. (1999). 'Philosophy in the Flesh: The Embodied Mind and its Challenge to Western Thought'. New York: Basic Books.

Luminant Design LLC (2014). '”A Definition of Communication Design'”. Retrieved 6 ${ }^{\text {th }}$ January, 2019 from: http://www.luminantdesign.com/definitions/communicationdesign.html

Metts, S. (2004). 'Introduction to Communication theory'. In John R. Baldwin, Stephen D. Perry, and Mary Anne Moffitt (Eds.), Communication theories for everyday life Boston: Pearson.

Merriam-webster.com, (2020) 'Definition of Graphic'. Retrieved, 18th ${ }^{\text {th }}$ May, 2020.From: https://www.merriam-webster.com/dictionary/graphic

Quora.com (2018). "What is the Scope of Communication Design?', Retrieved 6 ${ }^{\text {th }}$ January, 2019 from: https://www.quora.com/What-is-the-scope-of-communication-design

Singh, P. K. (2012). 'Management of Business Processes Can Help an Organization Achieve Competitive Advantage'. International Management Review, 8(2).

Society of Graphic Designers of Canada (2019). 'What is Graphic/Communication Design'. Retrieved $6^{\text {th }}$ January, 2019 from: https://gdc.design/design-buyers/what-is-graphic-design

Simplicable.com (2020) "Visual Communication". Retrieved, 18th ${ }^{\text {th }}$ May, 2020.From: https://simplicable.com/new/visual-communication

Study.com (2019). 'Defining Visual Communication'’. Retrieved, $6^{\text {th }}$ January, 2019.From: https:/study.com/academy/lesson/what-is-visual-communication-definition-history-theory-examples.html

Study.com (2020). "Communication Process'. Retrieved, 18th ${ }^{\text {th }}$ May, 2020.From: https://study.com/academy/lesson/what-is-the-communication-process-definition-steps.html

Tuckwell, K. J. (1992). 'Canadian advertising in Action'” ( $2^{\text {nd }}$ ed.). Ontario: Prentice -Hall Canada Inc. pp. 83, $85,103,106,365$ and 372

Wikipedia.org (2019). 'Graphic Design'. Retrieved $6^{\text {th }}$ January, 2019. From: https://en.wikipedia.org/wiki/Graphic_design\#History

\section{Authors Biography}

1st Author

Doctor Eric Agyarkoh is a Communication Design education lecturer at the Vocational and Technical Education Department, Faculty of Science and Technology Education, College of Education Studies, University of Cape Coast, Ghana. He researches mainly in communication design history in Ghana, communication design education, advertising and issues in Visual Arts. He holds Ph.D. and M. Phil. in Arts and Culture (Advertising), B. A. Graphic Design, HND Commercial Arts (Graphic Design Option), International Diploma in Advertising and Public Relations, Certificate in Education and Intermediate and Advanced certificates in Painting and Decorating.

2 Author

Helena Alice Mbil is a Junior Assistant Registrar in the printing section of University of Education, Winneba, Ghana. She researches in industrial printing, publication design, general communication design and arts and culture. She holds bachelor of Arts in graphic design and M. Phil. In Arts and Culture. She is currently a PhD candidate in Arts and Culture.

\section{Acknowledgements}

We wish to express our profound gratitude to the Headmasters and Assistant Headmasters of all the senior high 
schools in the Cape Coast metropolis that granted us permission to conduct the study in their schools. We are also grateful to all the Graphic Design tutors of the schools who spent their precious time to respond to the questionnaire and took part in the interview sessions. We have also acknowledged all the Internet sources we retrieved images from. All the images were free download images that did not require permission from owners to use.

\section{Funding}

The paper was not funded by any organisation. We funded it by ourselves.

\section{APPENDIX A: QUESTIONNAIRE FOR SHS GRAPHIC DESIGN TUTORS IN CAPE COAST}

Introduction

The emergence of digital revolution and the information age in the advanced countries in the 1960s, have broadened the scope of graphic design education and practice which hitherto was 'monomedia' to multimedia due to the introduction of new communication media (radio television, animation and internet). As a result, many tertiary institutions have adopted new names such as communication design, graphic communication design, visual communication design, etc. to replace the popular name graphic design. This development has created confusion among the public especially people who are less knowledgeable about the graphic design profession as to which of the names is appropriate for the profession.

This questionnaire aims at seeking the views and opinions of graphic design educators in senior high schools in the Cape Coast metropolis on various adopted names for the graphic design programme, and which of them must be accepted for the programme.

Please, feel free to participate in the study. we assure you of maximum confidentiality, anonymity and privacy.

Part A: Biodata of respondents (Please, tick or write the correct response $(s)$ )

Name of school.

1. Highest academic qualification (Non-education)

a) Ph. D.: Graphic design $\square$ Graphic Design related $\square$ Non- graphic design related $\square$

b) Second degree: Graphic design $\square$ Graphic Design related $\square$ Non- graphic design related $\square$

c) First degree: Graphic design $\square$ Graphic Design related $\square$ Non- graphic design related $\square$

d) HND Commercial/Industrial Art: Graphic design $\square$ Graphic Design related $\square$ Non- graphic design related $\square$

e) Other Tertiary diploma: Graphic design $\square$ Graphic Design related $\square$ Non- graphic design related $\square$

f) Certificate: Graphic design $\square$ Graphic Design related $\square$ Non- graphic design related $\square$

2. Highest professional qualification (Education or education related)
a) $\mathrm{Ph}$. D.
b) Second degree
c) First degree
d) Diploma
e) Certificate
f) None

3. Years of teaching graphic design
a) 1-5 years
b) 6-10 years
c) 11-15 years
d) 16-20 years
e) More than 20 years $\square$ 
Part B: Characteristics of adopted names (Please, tick the correct response $(s)$ )

\begin{tabular}{|c|c|c|c|c|c|c|}
\hline No. & Characteristics of Graphic Design & $\begin{array}{l}\text { Strongly } \\
\text { Agree }\end{array}$ & Agree & Disagree & $\begin{array}{l}\text { Strongly } \\
\text { Disagree }\end{array}$ & $\begin{array}{l}\text { Not } \\
\text { certain }\end{array}$ \\
\hline 4 & $\begin{array}{l}\text { Graphic design can combine text, illustration } \\
\text { and colour to communicate information }\end{array}$ & & & & & \\
\hline 5 & $\begin{array}{l}\text { Graphic design can combine only text and } \\
\text { illustration to communicate information }\end{array}$ & & & & & \\
\hline 6 & $\begin{array}{l}\text { Graphic design can use only text and colour to } \\
\text { communicate information }\end{array}$ & & & & & \\
\hline 7 & $\begin{array}{l}\text { Graphic design can use only illustration and } \\
\text { colour to communicate information }\end{array}$ & & & & & \\
\hline \multirow[t]{2}{*}{8} & $\begin{array}{l}\text { Graphic design can combine text, illustration, } \\
\text { colour and other visual elements to } \\
\text { communicate information }\end{array}$ & & & & & \\
\hline & $\begin{array}{l}\text { Characteristics of Graphic Communication } \\
\text { Design }\end{array}$ & & & & & \\
\hline 9 & $\begin{array}{l}\text { Graphic communication design can use the } \\
\text { same visual elements as Graphic design to } \\
\text { communicate information }\end{array}$ & & & & & \\
\hline \multirow[t]{2}{*}{10} & $\begin{array}{l}\text { Graphic communication design cannot use } \\
\text { the same visual elements as Graphic design to } \\
\text { communicate information }\end{array}$ & & & & & \\
\hline & Characteristics of Communication Design & & & & & \\
\hline 11 & $\begin{array}{l}\text { Communication design can use only one or } \\
\text { combines more than one visual element used } \\
\text { by Graphic design to communicate } \\
\text { information }\end{array}$ & & & & & \\
\hline 12 & $\begin{array}{l}\text { Communication design can combine audio, } \\
\text { video, animation, illustrations and text to } \\
\text { communicate information }\end{array}$ & & & & & \\
\hline 13 & $\begin{array}{l}\text { Communication design can use only audio to } \\
\text { communicate information }\end{array}$ & & & & & \\
\hline 14 & $\begin{array}{l}\text { Communication design can use only video to } \\
\text { communicate information }\end{array}$ & & & & & \\
\hline 15 & $\begin{array}{l}\text { Communication design can use only } \\
\text { animation to communicate information }\end{array}$ & & & & & \\
\hline \multirow[t]{2}{*}{16} & $\begin{array}{l}\text { Communication design can use only still- } \\
\text { images to communicate information }\end{array}$ & & & & & \\
\hline & $\begin{array}{l}\text { Characteristics of Visual Communication } \\
\text { Design }\end{array}$ & & & & & \\
\hline 17 & $\begin{array}{l}\text { Visual Communication design can use only } \\
\text { one or combines more than one visual element } \\
\text { used by Graphic design to communicate } \\
\text { information }\end{array}$ & & & & & \\
\hline 18 & $\begin{array}{l}\text { Visual Communication design can combine } \\
\text { video, animation, illustrations and text to } \\
\text { communicate information }\end{array}$ & & & & & \\
\hline
\end{tabular}

\section{APPENDIX B}

\section{INTERVIEW GUIDE FOR SHS GRAPHIC DESIGN TUTORS IN CAPE COAST}

Introduction

The emergence of digital revolution and the information age in the advanced countries in the 1960s, have broadened the scope of graphic design education and practice which hitherto was 'monomedia' to multimedia due to the introduction of new communication media (radio television, animation and internet). As a result, many tertiary institutions have adopted new names such as communication design, graphic communication design, visual communication design, etc. to replace the popular name graphic design.

This interview aims at seeking the views and opinions of graphic design educators in senior high schools in the Cape Coast metropolis on various adopted names for the graphic design programme and which of them must 
be accepted for the programme. Please, feel free to participate in the study. we assure you of maximum confidentiality, anonymity and privacy.

\section{Proposed Questions for Semi-structured Interview Guide}

Please, give your reason(s) for a response you give to every question.

1. Considering the longevity of using the name Graphic Design, do you think it should be changed?.

2. Can the change of name from Graphic design to a deferent name affect the brand and recognition of the programme among the public?.

3. Considering the current scope of the profession, do you think that a new name must be adopted to reflect all the communicate elements used in the profession?.

4. Should the name Graphic design be maintained for the programme in order to maintain the brand and identity of the programme?

5. Should we combine elements from different names to create an appropriate name for the programme?.

6. Considering the scope of the programme currently, which of the adopted names do you think is appropriate for the programme and why?

7. Can you suggest a different name for the programme and give your reasons? 